\title{
Effect of shipping boxes, attendant bees, and temperature on honey bee queen sperm quality (Apis mellifera)
}

\author{
Andrée Rousseau $^{1}$, Émile Houle ${ }^{1}$, Pierre Giovenazzo ${ }^{2,3}$ \\ ${ }^{1}$ Centre de Recherche en Sciences Animales de Deschambault, 120-A Chemin du Roy, Deschambault G0A 1S0, Canada \\ ${ }^{2}$ Département de biologie, Université Laval, Quebec 3044A, Canada \\ ${ }^{3}$ Faculté des Sciences et de Génie, Pavillon Vachon, Université Laval, Québec G1V 0A, Canada
}

Received 7 July 2019 - Revised 4 December 2019 - Accepted 26 February 2020

\begin{abstract}
The fertility and fecundity of the queen are vital to the success of a honey bee colony (Apis mellifera L.). Young mated queens are shipped worldwide to meet the demand of the beekeeping industry. Since little is known about the conditions experienced by queens in transit from breeders to beekeepers and the importance of these conditions on the queens' reproductive potential, we conducted a two-part study. First, queen shipments from the USA and Canada to Canadian beekeepers were monitored to measure thermal conditions during shipment. A total of 39 shipments were followed in 2017 and 2018. Monitoring revealed variable temperatures during shipment, with occasional periods of lows $\left(10-15^{\circ} \mathrm{C}\right)$ and highs $\left(30-36^{\circ} \mathrm{C}\right)$. Second, young mated queens were placed in different shipping boxes with or without attendant bees and exposed to one of three temperatures $\left(6^{\circ} \mathrm{C}, 26^{\circ} \mathrm{C}\right.$, and $\left.40{ }^{\circ} \mathrm{C}\right)$ for $2 \mathrm{~h}$. We then compared the thermoregulation within shipping boxes, and the viability of sperm in each queen's spermatheca. Our results show that both low and high temperatures significantly decrease sperm viability, and that the addition of loose attendant bees within shipment boxes helps maintain the temperature at $26^{\circ} \mathrm{C}$ when exposed to low temperature and delays the temperature increase when temperatures are high. The study shows the potential to improve current honey bee shipping methods in order to mitigate variable conditions experienced by bees during transportation.
\end{abstract}

honey bee queen / queen quality / shipment / temperature / sperm viability

\section{INTRODUCTION}

Honey bees (Apis mellifera L.) are eusocial insects, with a queen that is typically the only reproductive female. Once she has mated with many drones, usually between 6 and 21, approximately 4-9 million spermatozoa are stored inside her spermatheca for use during her reproductive life (Delaney et al. 2011; Kraus et al. 2005; Laidlaw and Page 1984; Tarpy et al. 2012; Seitz et al. 2016). A fertile queen will lay up to 1500 2000 eggs each day during the productive season

Corresponding author: A. Rousseau, andree.rousseau@crsad.qc.ca

Manuscript editor: David Tarpy
(Winston 1987). The queen also maintains the social cohesion of the colony by producing a wide variety of pheromones that influence workers' physiology and behavior (Pankiw et al. 1998; Hoover et al. 2003). Thus, the reproductive quality and health of a queen are essential to ensure colony growth, survival, and productivity (Delaney et al. 2011; De Souza et al. 2013).

Increasing reports of queen failure have been reported as the main cause of honey bee winter mortality in Canada (Bixby 2017; CAPA, 20102018) and in the USA (Brodschneider et al. 2010; Camazine et al. 1998; vanEngelsdorp et al. 2008, 2013). Furthermore, queen quality has been associated with premature supersedure, poor brood patterns, premature drone laying, and diminished longevity of queens (Amiri et al. 2017; Cobey 
et al. 2011; Rhodes 2008; van Engelsdorp and Meisner 2010). Biotic and abiotic factors have been linked to health and reproductive quality of queens (Alaux et al. 2011; Amiri et al. 2017; Pettis et al. 2016). For example, adverse climatic conditions affect larval development of queens and reduce their ultimate fecundity (De Souza et al. 2013; Tarpy et al. 2000). Overall, queen failure results in a drastically reduced adult bee population, which impacts colony development, honey production (Tarpy et al. 2000; vanEngelsdorp et al. 2013), and the ability of a colony to withstand winter conditions in temperate environments.

Honey bee queens are shipped worldwide, and the Canadian beekeeping industry relies on hundreds of thousands of commercially reared queens shipped by air or ground transportation (Pettis et al. 2016; Sammataro et al. 1999). Between 2010 and 2016, queen imports to Canada increased by $505 \%$, and in 2018 , more than 260,000 queens were imported from the USA, New Zealand, Australia, and Chile for a total value of more than $\$ 8$ million CAD (Agriculture and Agri Food Canada 2018). Queens are usually shipped in small plastic or wooden cages along with 4-12 young worker bees and an opening filled with sugar candy to provide food during shipment and delays in the introduction of the queen into the colony (Büchler et al. 2013). Monitoring the environmental conditions within queen shipment boxes in transit from breeders to customers in the USA and Canada showed temperature fluctuations ranging from -6.7 to $42.8{ }^{\circ} \mathrm{C}$ (Sammataro et al. 1999) with temperature spikes of less than $8^{\circ} \mathrm{C}$ and more than $40^{\circ} \mathrm{C}$ (Pettis et al. 2016). While honey bee colonies can regulate the thermal conditions inside the nest, small groups of bees in queen shipping boxes have limited possibilities for buffering environmental extremes and are at the mercy of ambient temperature (Free and Spencer-Booth 1958). Recently, Pettis et al. (2016) showed that extreme temperature reduced viability of sperm inside queen spermatheca. When queens were exposed to low $\left(4^{\circ} \mathrm{C}\right)$ or high temperature $\left(40^{\circ} \mathrm{C}\right)$ for $2 \mathrm{~h}$, sperm viability inside queen spermatheca decreased to nearly $20 \%$.

A better understanding of the various factors influencing the reproductive potential of queens is required to ensure the quality of queens and productivity of colonies for the beekeeping industry. Therefore, this study was conducted to obtain information on the environmental conditions experienced by honey bee queens shipped within Canada and from the USA to Canada. A second objective was to test the influence of queen shipping methods and the effect of temperature on queen fertility, and measuring effects on thermoregulation inside queen shipping boxes, queen morphometric measurements, and sperm viability within queen spermatheca. We hypothesized that queens are exposed to highly variable conditions when shipped to Canadian beekeepers, and that the addition of attendant bees can improve thermoregulation and help preserve queen fertility.

\section{MATERIAL AND METHODS}

\subsection{Queen shipments}

Thirty-nine United Postal Service and Canada Post honey bee queen shipments from two queen breeders (Api Culture Hautes-Laurentides in Ferme-Neuve, Québec, Canada and Pope Canyon Queens in Vacaville, California, USA) were monitored during spring and summer 2017 and 2018. Data loggers (Hobo data logger U12-O13, Hoskin Scientific) were fixed in the middle of the shipment box with Velcro strips to record temperature and relative humidity in one queen shipping box of each shipment.

\subsection{Queen rearing}

Queen rearing and experiments were conducted at the Centre de Recherche en Sciences Animales de Deschambault (CRSAD, Deschambault, $46^{\circ}$ $\left.40^{\prime} 26,85^{\prime \prime} \mathrm{N}, 71^{\circ} 54^{\prime} 54.39^{\prime \prime} \mathrm{W}\right)$ in Deschambault, Québec, Canada. In July 2017, young mated sister queens were bred using the Cloake Board Method (Cobey 2005). Briefly, young larvae were grafted from a single-mother colony and introduced into cell-builder colonies. After 10 days, each queen cell was introduced into a nucleus colony, into which the virgin queen subsequently emerged. Two weeks later, mated laying queens were ready for experimental trials. 


\subsection{Simulated shipping methods and temperatures}

Seventy-two mated queens were distributed randomly into experimental groups exposed to various queen-shipping methods and temperatures (Figure 1). We tested three temperatures $(2 \mathrm{~h}$ at either $6^{\circ} \mathrm{C}, 26^{\circ} \mathrm{C}$, or $40^{\circ} \mathrm{C}$ ), two types of shipping boxes (plastic Jz-Bz battery box or Riteway cardboard box), and the presence or absence of attendant bees on thermoregulation inside queen boxes, queen morphometric measurements, and sperm viability within queen spermatheca. Attendant bees were added with a graduated cup inside each box: approximately 250 attendants in Jz-Bz battery box and 500 in each Riteway cardboard box. Queen bees were exposed to extreme 6 and $40{ }^{\circ} \mathrm{C}$ previously found by Pettis et al. (2016) and $26{ }^{\circ} \mathrm{C}$ was chosen as control temperature because it was the mean temperature found in commercial honey bee queen shipments in 2017 and 2018. Each experimental combination had six replicates (shipping boxes) and each shipping box contained 20 individual queen $\mathrm{Jz}-\mathrm{Bz}$ cages but only one had a queen with attendant bees, the others had only attendant bees to mimic a full shipment box of 20 queen cages. Trials were performed in an environmental chamber with controlled temperature and humidity in darkness. Temperature sensors (Thermocouple wire $\mathrm{T}$ type GG-T-20-50, Omega) were placed in the middle of two queen shipping boxes per experimental combination (shipping box $\times$ attendant or not) to record the internal temperature of the shipping box every $10 \mathrm{~min}$ and a sensor was also placed in the middle of the incubator to record the incubator temperature. The experiments were all performed the day after collection of the mated queens from their nucleus; the same incubator was used to perform the three exposition periods $(2 \mathrm{~h}$ at either $6{ }^{\circ} \mathrm{C}, 26{ }^{\circ} \mathrm{C}$, or $40{ }^{\circ} \mathrm{C}$ ) but different queens were used in each trial. After each trial, all queen cages were placed together in a single queenless bank, with young bees and food for an additional 6 days.

\subsection{Honey bee queen evaluation}

In addition to the 72 queens of the experimental groups, a group of five queens was used to obtain Springer initial values of queen fertility and morphometric measurements of queen size (head, thorax and abdomen width/length, fresh weight, and sperm viability (Büchler et al. 2013)). The abdomens of queens were dissected to remove the spermatheca according to the methodology described by Collins and Donoghue (1999). Each spermatheca was ruptured and homogenized in $0.5 \mathrm{ml}$ of modified Kiev Buffer (Moritz 1984; 0.3 g D+ Glucose, 0.41 potassium chloride, $0.21 \mathrm{~g}$ sodium bicarbonate, 2.43 g sodium citrate 2 hydrate, $0.05 \mathrm{~g}$ streptomycin in $100 \mathrm{ml}$ of deionized water). Sperm dilution was stained with a Live/Dead Sperm Viability Kit (L-7011; Life Technology Inc., Burlington, Ontario, Canada) using SYBR-14 and propidium iodide. Sperm viability was assessed using a Zeiss Observer Z1 microscope equipped with fluorescence filters by scoring live and dead sperms for 200 cells on four slides of $10-\mu \mathrm{L}$ stained semen.

\subsection{Statistical analysis}

All statistical computations were carried out using $\mathrm{R}$ language ( $\mathrm{R}$ Development Core Team 2008). Repeated-measures analysis of variance was used to verify differences between the experimental groups. A three-factor analysis of variance (fixed effects: temperature, shipping box type, and presence of attendant bees) was performed to compare morphometric measurements of queens and sperm viability between experimental groups. To meet the premise of the model, the arcsine transformation was used on the percentage of sperm viability and LSmeans was used to compare groups.

\section{RESULTS}

\subsection{Queen shipments}

The 39 honey bee queen shipments followed in 2017 and 2018 contained up to 840 queens. Results showed minimum and maximum temperatures of $12.4{ }^{\circ} \mathrm{C}$ and $34.7{ }^{\circ} \mathrm{C}$ inside the 152,017 queen shipment boxes (average $25.0 \pm 3.1{ }^{\circ} \mathrm{C}$; Figure 2) and $10.6{ }^{\circ} \mathrm{C}$ and $34.4{ }^{\circ} \mathrm{C}$ for the 232,018 shipments (average $24.7 \pm 3.5{ }^{\circ} \mathrm{C}$; Figure 3 ). Relative humidity ranged from 27.4 to $66.7 \%$ (average $49.8 \%$ ) in 2017 and 15.1 to 


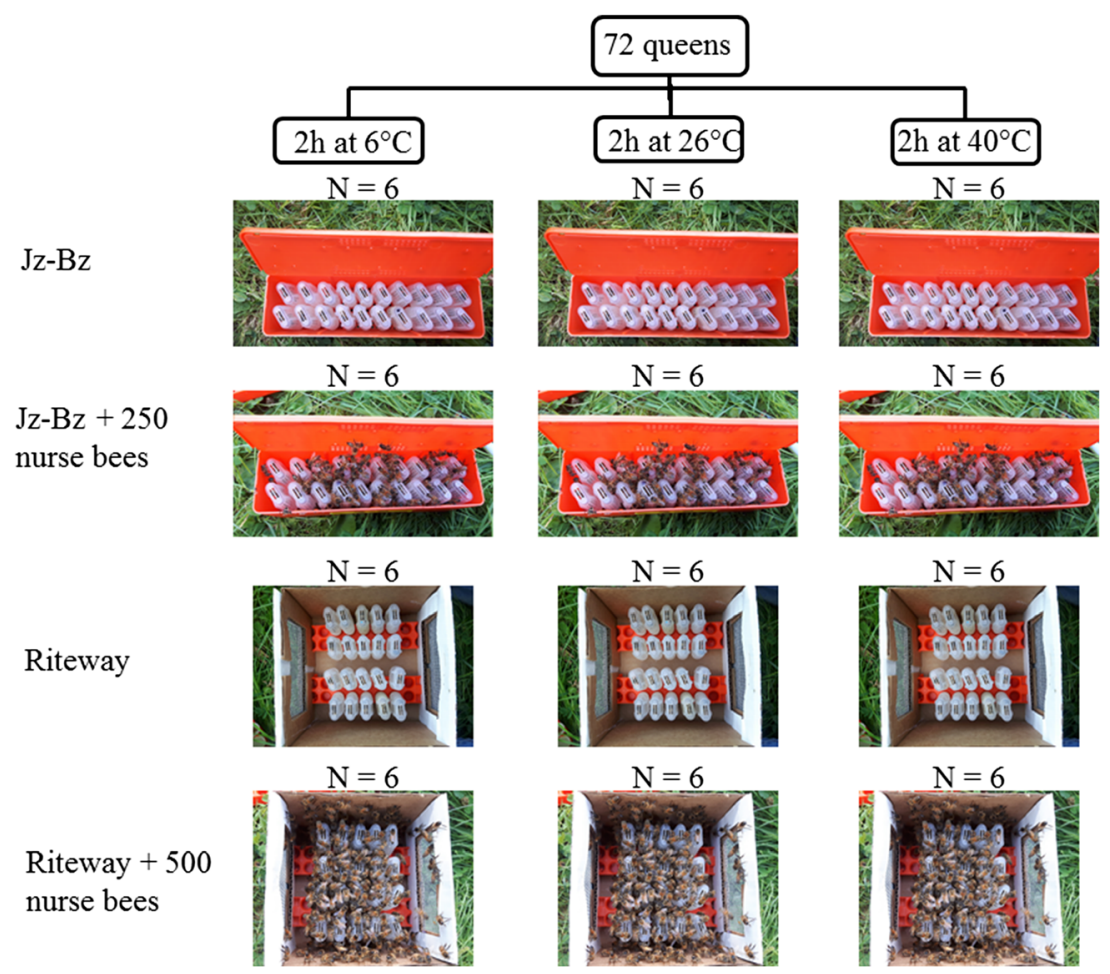

Figure 1. Experimental design diagram. Each experimental combination has six replicates $(N=6)$. Jz-Bz battery boxes or Riteway cardboard boxes contain 20 individual queen boxes but only one has a queen with four attendant bees, the others have only bees to mimic a full shipment box of 20 queen plastic Jz-Bz cages.

$71.4 \%$ in 2018 (average 47.2\%). Shipments took an average of $30.5 \mathrm{~h}$ to reach postal outlet (range 16-69 h).

\subsection{Simulated shipping methods and temperatures}

Exposure to $6{ }^{\circ} \mathrm{C}$ or $40{ }^{\circ} \mathrm{C}$ significantly affected internal shipping box temperature. When shipping boxes were exposed to $6^{\circ} \mathrm{C}$ for $2 \mathrm{~h}$, there was no combined effect of the container type with the presence of attendant bees $\left(\mathrm{F}_{(1,4)}=1.18, P=\right.$ 0.3384 ) and the type of shipping box had no effect on the temperature inside the box $\left(\mathrm{F}_{(12,48)}=\right.$ $1.2226, P=0.2959)$. However, there was a significant effect of the presence of attendant bees $\left(\mathrm{F}_{(12,48)}=105.7980, P=0.0005\right.$, Figure 4). Average temperature inside boxes with attendant bees was significantly higher during the exposure at $6{ }^{\circ} \mathrm{C}$ and never dropped below $25^{\circ} \mathrm{C}$ in average (range $24.0-26.6^{\circ} \mathrm{C}$ after $130 \mathrm{~min}$ ), compared to boxes without attendant bees, in which the temperature decreased gradually to $13{ }^{\circ} \mathrm{C}$ in average (range $11.8-15.1^{\circ} \mathrm{C}$ after $130 \mathrm{~min}$ ).

When shipping boxes were exposed to control temperature $\left(26^{\circ} \mathrm{C}\right)$ for $2 \mathrm{~h}$, there was no combined effect of the container type with the presence of attendant bees $\left(\mathrm{F}_{(1,4)}=2.217, P=\right.$ $0.2107)$. At mean temperature found in commercial shipments, adding attendant bees had no effect on the inside temperature of the boxes $\left(\mathrm{F}_{(12,48)}=1.944, P=0.0521\right)$ but there was a significant effect of the box type $\left(\mathrm{F}_{(12,48)}=2.575\right.$, $P=0.0101$, Figure 5). Temperature recorded inside Jz-Bz shipping boxes was significantly higher than in Riteway shipping boxes only after $80 \mathrm{~min}$ (increase of $1.14^{\circ} \mathrm{C}$ ).

When shipping boxes were exposed to $40{ }^{\circ} \mathrm{C}$ for $2 \mathrm{~h}$, no interaction between the container type and the presence of attendant bees on the internal temperature $\left(\mathrm{F}_{(1,4)}=1.85, P=0.2450\right)$. Also, adding attendant bees had no effect $\left(\mathrm{F}_{(12,48)}=\right.$ 
a

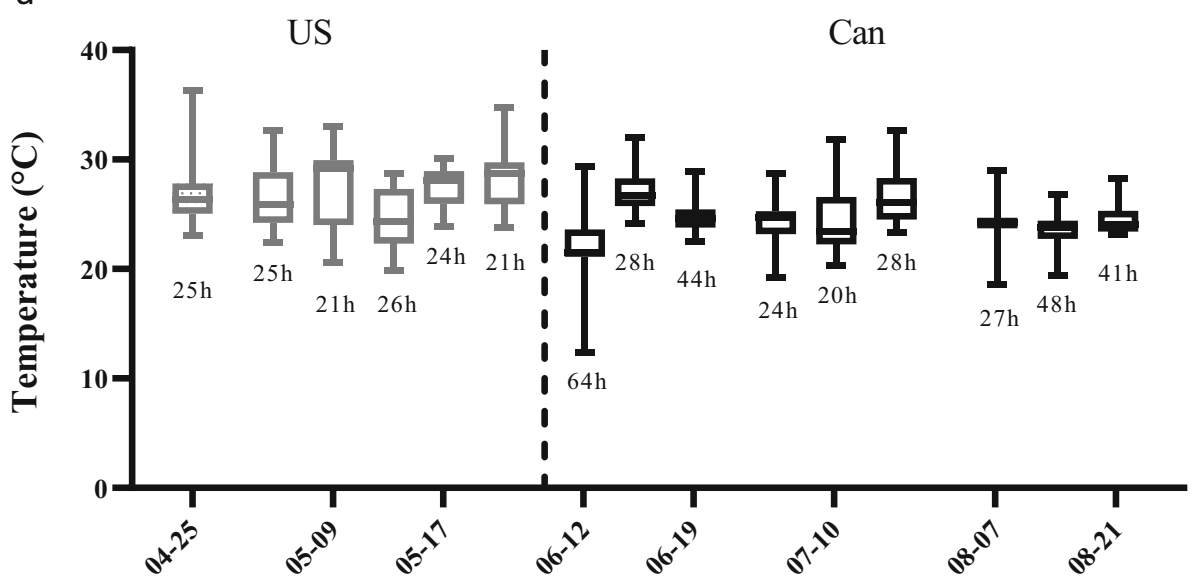

b

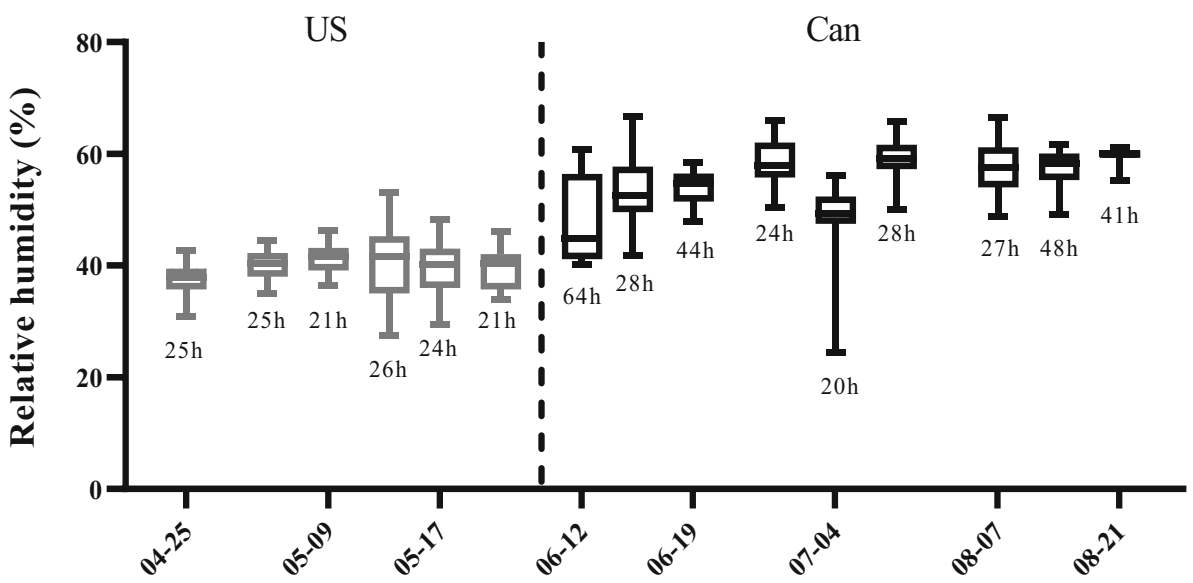

Figure 2. a Temperature $\left({ }^{\circ} \mathrm{C}\right)$ and $\mathbf{b}$ relative humidity $(\%)$ recorded inside 15 commercial honeybee queen shipping boxes for each shipment followed in 2017. Duration of transport is shown under each box.

1.38, $P=0.2090$ ), but there was a significant effect of the box type $\left(\mathrm{F}_{(12,48)}=11.13\right.$, $P<.0001)$ at time intervals of $0,20,30,40$, and $50 \mathrm{~min}$, with the temperature inside Riteway boxes higher than in Jz-Bz containers, indicating that they may take longer to overheat (Figure 6). After $50 \mathrm{~min}$, temperatures were similar in all shipping boxes and averaged $39.5 \pm 0.1{ }^{\circ} \mathrm{C}$.

\subsection{Honey bee queen evaluation}

All queens survived the various experimental trials except four that died during the week following the experiment: one queen from the group exposed to $40{ }^{\circ} \mathrm{C}$ in a Jz-Bz shipping box without attendant bees, one queen from the group exposed to $6{ }^{\circ} \mathrm{C}$ in a Riteway shipping box without attendant bees, and two queens from the group exposed to $26{ }^{\circ} \mathrm{C}$ (one in a Jz-Bz shipping box with attendant bees and the other in a Riteway shipping box without attendant bees). There was no effect of treatment on queen morphometric measurements; the queens in our study weighed an average of $189.4 \pm 17.8 \mathrm{mg}$, had a mean thorax width of $4.84 \pm 0.26 \mathrm{~mm}$, a mean abdomen width of $4.94 \pm 0.30 \mathrm{~mm}$, and a mean abdomen length of $10.03 \pm 0.99 \mathrm{~mm}$.

Queens evaluated at time 0 showed $84.9 \pm$ $1.79 \%$ of sperm viability. Sperm viability was 


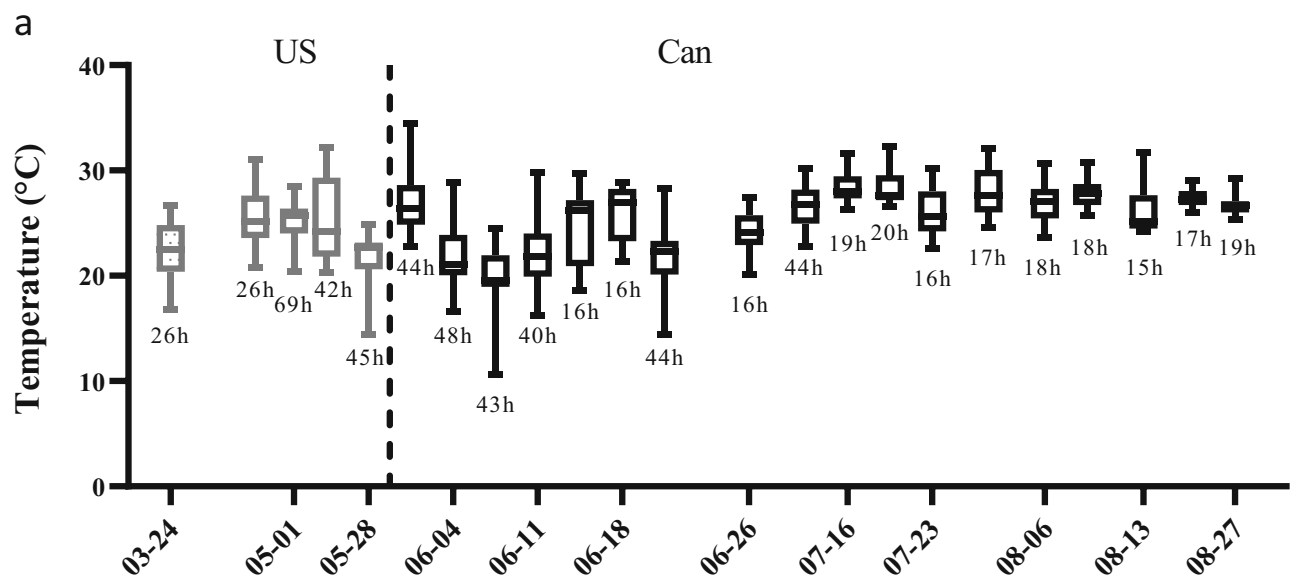

b US Can

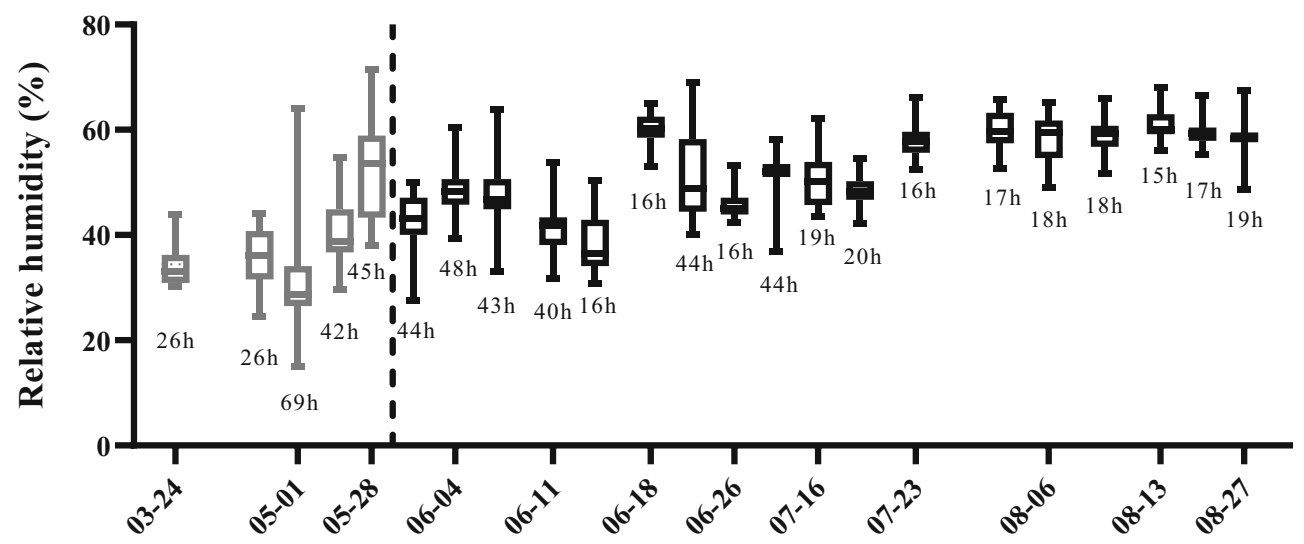

Figure 3. a Temperature $\left({ }^{\circ} \mathrm{C}\right)$ and $\mathbf{b}$ relative humidity $(\%)$ recorded inside 23 commercial honeybee queen shipping boxes for each shipment followed in 2018. Duration of transport is shown under each box.

not affected by the type of shipping box when exposed to either 6,26 , or $40{ }^{\circ} \mathrm{C}\left(\mathrm{F}_{(2,39)}=\right.$ 2.8250, $P=0.1008)$ nor by the presence or absence of attendant bees $\left(\mathrm{F}_{(1,39)}=0.1057, P=\right.$ 0.7468 ), or the interaction between containers and attendant presence $\left(\mathrm{F}_{(1,4)}=1.0750, P=\right.$ $0.3062)$. However, in all containers/attendant treatments, sperm viability was affected by temperature exposure $\left(\mathrm{F}_{(2,39)}=7.3948, P=0.0019\right)$; when exposed to either low- or high-temperature scenario, sperm viability of queens was reduced (respectively $68.5 \pm 1.42 \%$ and $69.7 \pm 1.73 \%$ ) compared to the group of queens exposed to control temperature $(79.4 \pm 1.44 \%)$.

\section{DISCUSSION}

\subsection{Commercial shipments}

The first aim of this study was to evaluate the conditions under which honey bee queens are shipped to or within Canada. Our results confirmed that queens continue to be exposed to variable conditions (temperature and relative humidity), as was found previously (Pettis et al. 2016; Sammataro et al. 1999). Furthermore, monitoring queen shipments from California and Québec revealed thermal conditions likely to cause a chill coma in bees $\left(10-15^{\circ} \mathrm{C}\right)$, defined as the highest 


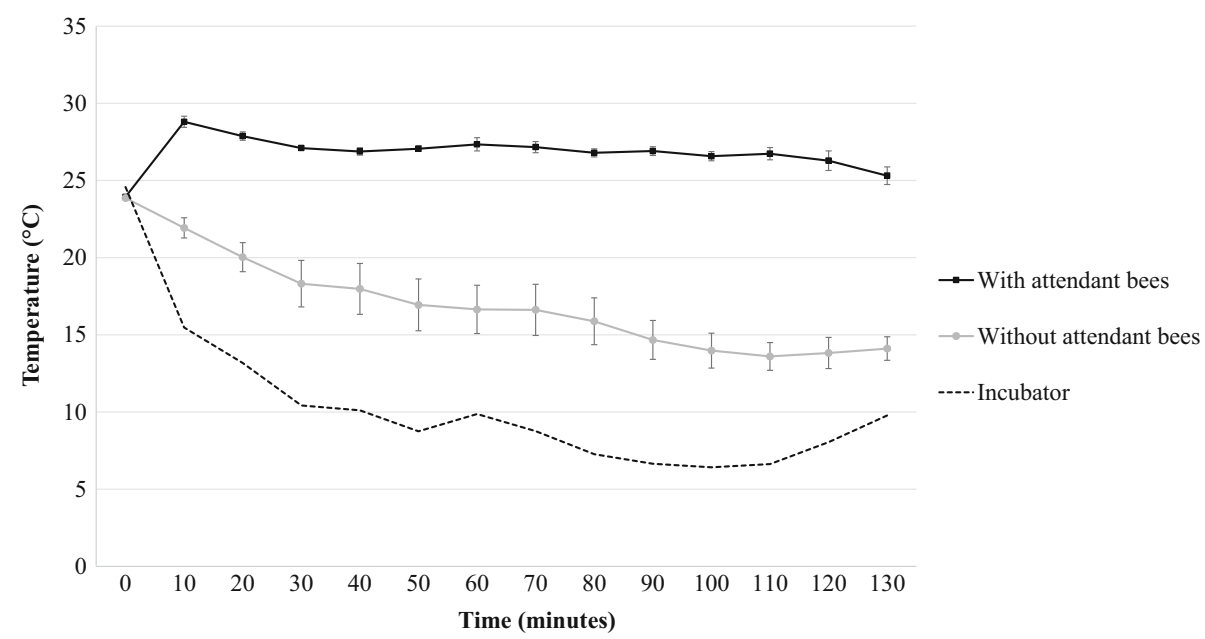

Figure 4. Temperature of the environmental incubator (dashed line) and temperature recorded inside queen boxes $\left({ }^{\circ} \mathrm{C}\right) \pm \mathrm{SE}$ with or without attendant bees for both type of boxes combined for the $2 \mathrm{~h}$ of exposure to $6{ }^{\circ} \mathrm{C}\left(\mathrm{F}_{(12,48)}=\right.$ 105.7980, $P=0.0005)$.

temperature at which bees are immobilized by cold (Free and Spencer-Booth 1960). A honey bee colony can tolerate a wide range of temperatures, but when the individual honey bee body temperature reaches $9-13{ }^{\circ} \mathrm{C}$, it enters a coma characterized by absence of excitability in muscles and nerves (Esch 1988; Goller and Esch 1990; Free and SpencerBooth 1958; Southwick and Heldmaier 1987). Free and Spencer-Booth (1958) exposed groups of 10,
$25,50,100$, and 200 honey bees to low temperatures. They found that below $15{ }^{\circ} \mathrm{C}$ there is a significant increase of bee clustering in groups of all sizes, particularly in groups of 10 and 25 bees. Our study showed that four honey bee shipments between late May and mid-June were exposed to near chill coma temperatures and that these conditions lasted from 40 to $290 \mathrm{~min}$. Interestingly, these temperatures were recorded only in shipments

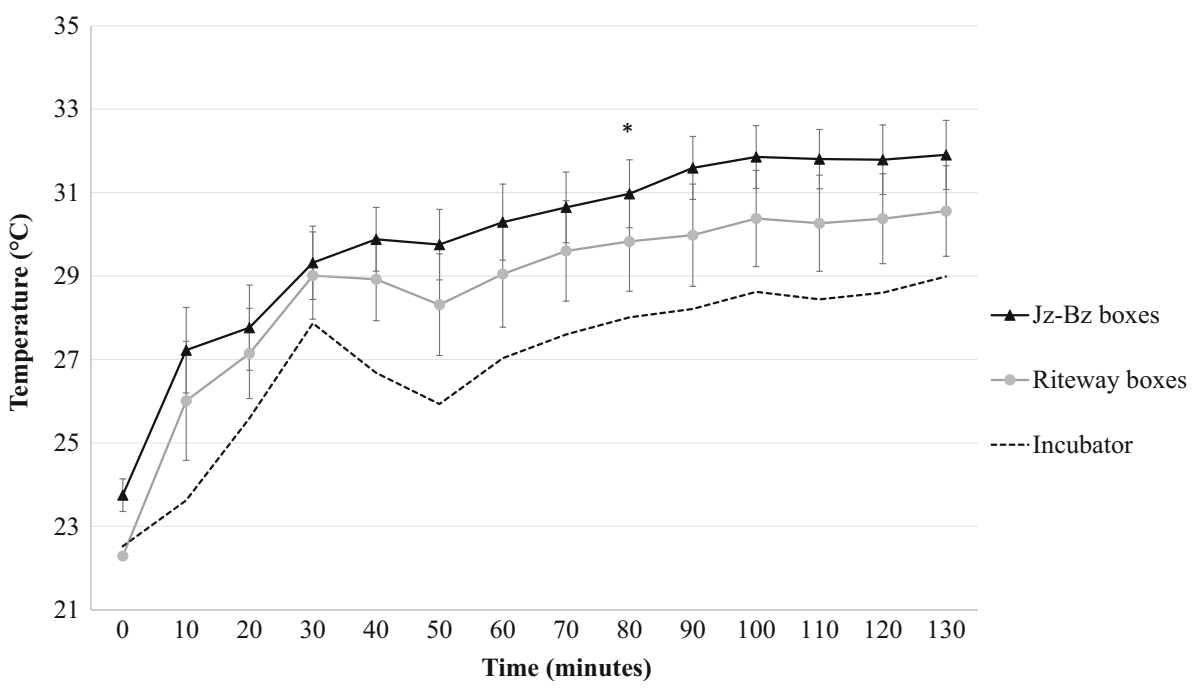

Figure 5. Temperature of the environmental incubator (dashed line) and temperature recorded inside queen boxes $\left({ }^{\circ} \mathrm{C}\right) \pm \mathrm{SE}$ inside $\mathrm{Jz}-\mathrm{Bz}$ and Riteway boxes with and without attendant bees combined for the $2 \mathrm{~h}$ of exposure to $26^{\circ} \mathrm{C}$ $\left(\mathrm{F}_{(12,48)}=2.575, P=0.0101\right)$. 


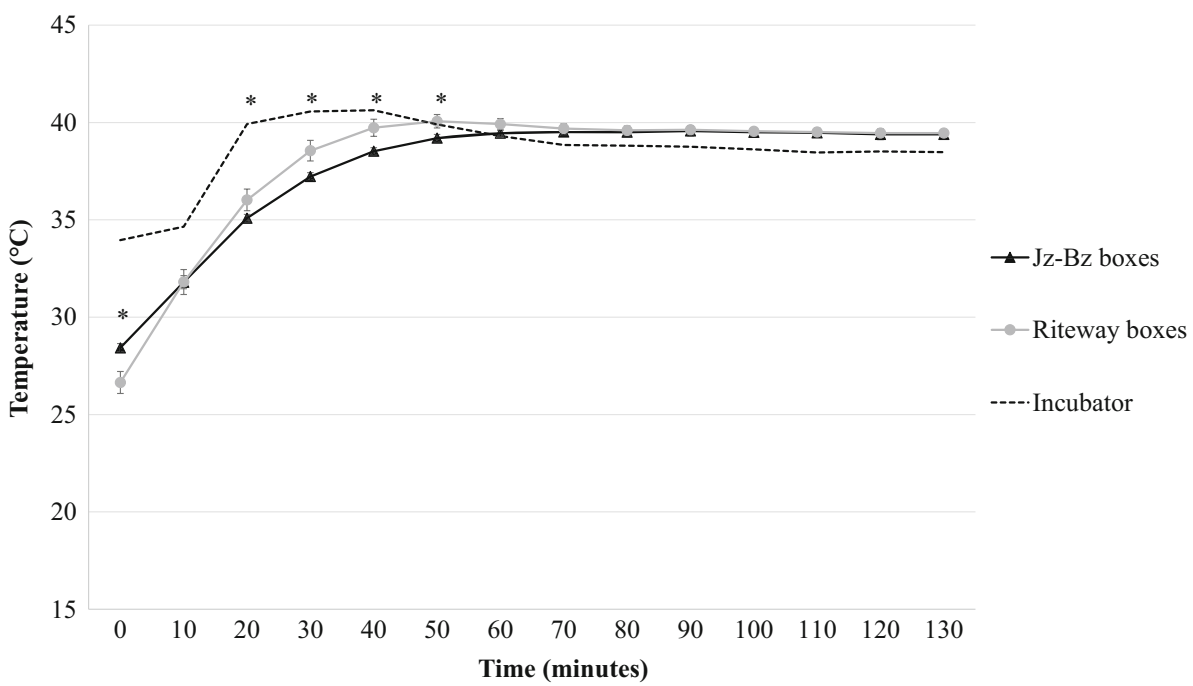

Figure 6. Temperature of the environmental incubator (dashed line) and temperature recorded inside queen boxes $\left({ }^{\circ} \mathrm{C}\right) \pm \mathrm{SE}$ inside $\mathrm{Jz}-\mathrm{Bz}$ and Riteway boxes with and without attendant bees combined for the $2 \mathrm{~h}$ of exposure to $40^{\circ} \mathrm{C}$ $\left(\mathrm{F}_{(12,48)}=11.13, P<.0001\right)$.

containing a low number of queens ( 3 to 17 ), while the others showed an acceptable temperature (16 to $35^{\circ} \mathrm{C}$ ) and were composed of at least 25 and as many as 840 queens. The impact of the number of queens inside honey bee shipment boxes on the inner temperature of shipping boxes should be further investigated to evaluate if the size of the shipment could influence the thermoregulation and if breeders and beekeepers would benefit sending queens in larger numbers to minimize deleterious effect of low temperature. Relative humidity recorded inside commercial queen shipments was also variable and ranged from 15 to $71 \%$. Inside the honey bee colony, humidity is regulated through evaporation of water and nectar, and optimal humidity differs between the brood area and nectar stores (Human et al. 2006). However, without access to water or nectar, relative humidity depends on temperature, as the saturation vapor density of water in air increases with air

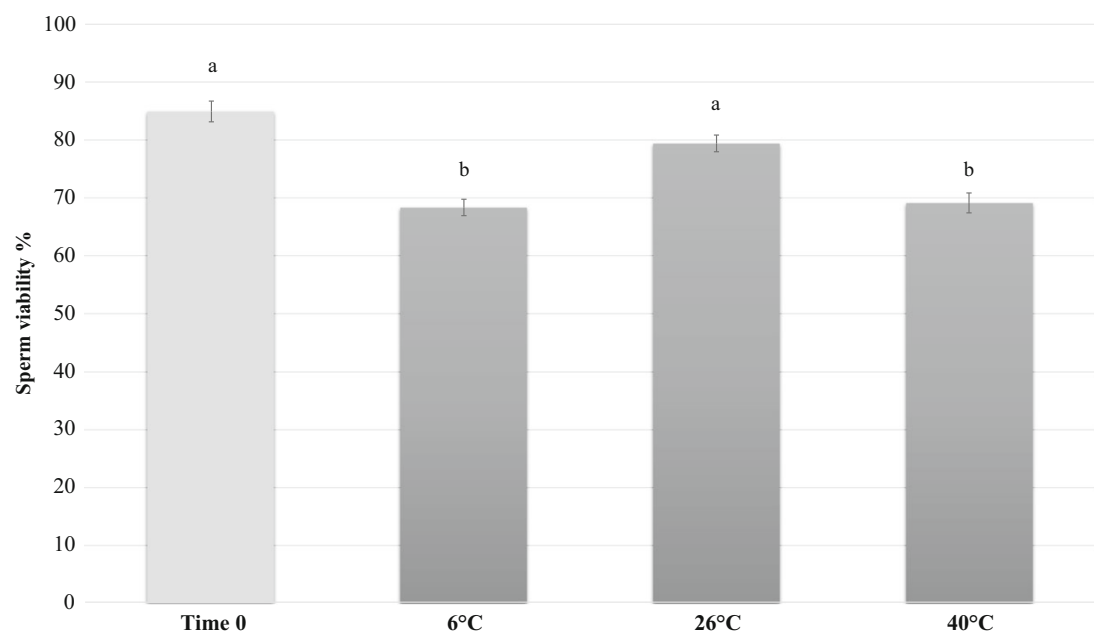

Figure 7. Sperm viability percentage inside queen spermatheca evaluated at time 0 and after $2 \mathrm{~h}$ exposed at 6, 26, or $40{ }^{\circ} \mathrm{C}\left(\mathrm{F}_{(2,39)}=7.3948, P=0.0019\right)$. 
temperature. To date, little is known about the optimum humidity for queens in shipment and further research is required.

\subsection{Thermoregulation}

Our results showed that 250-500 attendant bees can thermoregulate the internal environment of the shipment box during exposure to $6{ }^{\circ} \mathrm{C}$ and partly during exposition at $40{ }^{\circ} \mathrm{C}$. This thermoregulation was dependent on the shipping box type and the presence of loose bees inside shipment boxes. At $6{ }^{\circ} \mathrm{C}$, the presence of loose bees improved thermoregulation inside queen shipment boxes and maintained the temperature above $25^{\circ} \mathrm{C}$. The absence of these bees resulted in a temperature decrease to a near-coma level. Although, when exposing queen shipments to high temperature, bees nor shipment boxes were not sufficient to maintain the temperature below $35^{\circ} \mathrm{C}$ and that temperature reaches this point in all queen boxes after $20 \mathrm{~min}$. Beekeepers should be aware that both low and high temperatures can lead to deleterious conditions for queens, especially when no additional attendant bees are present inside shipment boxes to improve thermoregulation. In this study, only one queen was placed in each box and despite the fact that the queen was randomly assigned to a position inside the shipping box, which could have affected the behavior of loose attendants in the shipment. We found no indication that bees were clustering around one cage when opening shipment boxes after each trial but further experiments are necessary to understand workers' behavior in relation to the number of queens in shipments. The adequate number of attendants inside a queen shipment should also be investigated in order to overcome a wide range of fieldrealistic thermal conditions during shipping of bees. In this study, we found a thermoregulation effect at low temperature for both 250 and 500 attendant bees added to shipments, indicating that those numbers can be used to compensate for low temperature found in small queen shipments found at the beginning of the beekeeping season.

Honey bees are heterothermic insects. Their body temperature can either change passively according to ambient temperature (ectothermy) or they can actively regulate their internal body temperature in accordance with the ambient environment (endothermy) by using the heat from their abdominal muscle contractions (Guo et al. 2018; Stabentheiner et al. 2012). The optimal brood nest temperature is $33-36{ }^{\circ} \mathrm{C}$ (Kleinhenz et al. 2003) and workers regulate the temperature to maintain it within this range by wing fanning and water intake, which evaporate hot air out of the nest, or clustering together and generating metabolic heat at low temperatures. The consequences for the colony of shifting away from optimum temperature during brood development can include increased malformations and mortality of the brood, reduced waggle dance performance, impaired learning and memory capacities, and possible increased susceptibility to pesticides in adult worker bees (Medrzycki et al. 2010; Tautz et al. 2003). Queens are known to be resilient and to survive considerable range of temperature and conditions during short-term storage (Nelson 1987; Reid 1975; Szabo et al. 1987), however, the full consequences of periods of non-optimal nest temperatures early in the queen's life are poorly understood. In this study, when queen shipments were exposed to the average temperature found in commercial shipments $\left(26^{\circ} \mathrm{C}\right)$ without any extreme temperature, bees kept an average temperature of $30^{\circ} \mathrm{C}$, suggesting that this could be an optimal for queens and bees outside the nest.

\subsection{Queen morphometric measurements and sperm viability}

The other aim of this study was to measure queen sperm viability within her spermatheca following our various shipment simulations. Despite thermoregulation at low temperature when there are more attendant bees, sperm viability was not significantly higher. Nevertheless, low and high thermal scenarios resulted in a $12-14 \%$ decrease of sperm viability inside queen spermatheca. Quality of commercially produced queens have been found to be generally high (Tarpy et al. 2012; Delaney et al. 2011) with some variations in queens' reproductive potential. Pettis et al. (2016) results suggested a link between low sperm viability and failing colonies by looking at sperm viability of failing queens identified by beekeepers and suggested that exposition of queens to extreme 
temperature could be one explanation. Withrow et al. (2019) recorded the temperatures experienced by queens shipped in bee packages and tracked the survival of the queen as well as the buildup of the colony. They found $25 \%$ queen failure and while they found no indication that those failures were caused by temperature-related damage, they found failing queens experienced higher average temperature and lower temperature variability. Our findings confirm the impact of a 2-h exposure at temperatures of $6{ }^{\circ} \mathrm{C}$ or $40{ }^{\circ} \mathrm{C}$ on the reproductive potential of queens and economic consequences of the possible decrease sperm viability of commercially sold queens are clear: within a spermatheca containing five million sperm, $12-14 \%$ less viability means 600,000 to 700,000 dead sperms attributed to extreme temperature exposure. The negative effect of exposure to extreme temperature on sperm viability has previously been found for drones: exposure to either $6{ }^{\circ} \mathrm{C}$ or $40{ }^{\circ} \mathrm{C}$ results in $40 \%$ more dead sperm in drone ejaculate and fewer spermatozoa inside the queen's spermatheca (Bieńkowska et al. 2011). Our results confirm the need to avoid extreme temperature exposition for high-quality queens in a commercial context.

\section{CONCLUSION}

In this study, exposure of queens to $6{ }^{\circ} \mathrm{C}$ or $40{ }^{\circ} \mathrm{C}$ for $2 \mathrm{~h}$ adversely affected queen fertility. This highlights the need to improve the environmental conditions under which queens are shipped from breeders to beekeepers by air or ground transportation. This study also demonstrates the importance of keeping queens from temperature fluctuations while they are outside the hive environment, from their handling before shipment to their transportation by beekeepers in the field before introduction in the colony. The addition of attendant bees inside shipments can help mitigate unpredictable exposure to low temperatures, however, high temperatures remain risky as attendant workers are unable to compensate and temperatures inside shipping containers reach levels that damage sperm. More research is necessary to evaluate the best methods for shipping queens under a wide range of conditions. Furthermore, queen longevity and success inside the colony must be subsequently evaluated to determine the non-lethal effects of shipping conditions. Monitoring queen shipments illustrates the challenges of maintaining environmental conditions that will ensure the fertility and fecundity of young mated queens.

\section{ACKNOWLEDGMENTS}

In addition to the administrative staff, the authors would like to thank the beekeeping team of the Centre de Recherche en Sciences Animales de Deschambault as well as the students involved in the project, Noémie Lampron, Marie-Lou Morin, and Ségolène Maucourt. Special thanks to queen breeders Anicet Desrochers and Caroline Yelle for their help collecting data pertaining to commercial honey bee queen shipments and their input during the project.

\section{AUTHOR CONTRIBUTIONS}

A.R. and P.G. conceived and designed the described experiments; A.R et E.H conducted the experiments, A.R. analyzed the resulting data; A.R. and P.G. wrote the paper and participated in its revision. All authors approved the final manuscript.

\section{FUNDING INFORMATION}

This project was funded by the Canadian Agricultural Adaptation Program (2014-2019) of Agriculture and Agri-Food Canada, the Centre de recherche en sciences animales de Deschambault, and also received financial support from the $\mathrm{Ca}$ nadian Bee Research Fund and the Bee Maid research fund.

Influence des boîtes d'expédition, des abeilles accompagnatrices et de la température sur la qualité de sperme dans les reines d'abeille (Apis mellifera).

reine abeilles / qualité de la reine / transport / température / viabilité du sperme.

Der Einfluss von Versandbehältern, Begleitbienen und Temperatur auf die Qualität des Spermas bei Honigbienen-Königinnen (Apis mellifera).

Honigbienen/ Königin/ Königinnenqualität/ Transport/ Temperatur/ Spermienvitalität. 


\section{REFERENCES}

Agriculture and Agri Food Canada. (2018) Statistical Overview of the Canadian Honey and Bee Industry and the Economic Contribution of Honey Bee Pollination, 2018.

Alaux C., Folschweiller M., McDonnell C., Beslay D., Cousin M., Dussaubat C., Brunet J.L., Le Conte Y. (2011) Pathological effects of the microsporidium Nosema ceranae on honey bee queen physiology (Apis mellifera ). J. Invertebr. Pathol. 106(3), 380-385

Amiri E., Strand M., Rueppell O., Tarpy D. (2017) Queen quality and the impact of honey bee diseases on queen health: potential for interactions between two major threats to colony health. Insects $8(2), 48$

Bieńkowska M., Panasiuk B., Wegrzynowicz P., Gerula D. (2011) The effect of different thermal conditions on drone semen quality and number of spermatozoa entering the spermatheca of queen bee. J. Apic. Sci $\mathbf{5 5}(2), 161-168$

Bixby M. (2017) A Canadian beekeeping perspective on colony health and growing our local queen supply. HiveLights 30 (1), 13-15

Brodschneider R., Moosbeckhofer R., Crailsheim K. (2010) Surveys as a tool to record winter losses of honey bee colonies: a two year case study in Austria and South Tyrol. J. Apic. Res. 49(1), 23-30

Büchler R., Andonov S., Bienefeld K., Costa C., Hatjina F., Kezic N., Kryger P., Spivak M., Uzonov A., Wilde J. (2013) Standard methods for rearing and selection of Apis mellifera queens. J. Apic. Res. 52 (1), 1-30

Camazine S., Cakmak I., Cramp K., Fisher J., Frazier M., Rozo A. (1998) How healthy are commerciallyproduced US honey bee queens? Am. Bee J. 138, 677-680

Canadian Association of Professional Apiculturists (2018) CAPA Statement on Colony Losses in Canada

Cobey S. (2005) A versatile queen rearing and banking system-part 1 the "Cloake board method" of queen rearing. Am. Bee J. 145 (4), 308-311

Cobey S., Sheppard W.S., Tarpy D.R. (2011) Status of Breeding Practices and Genetic Diversity in Domestic US Honey Bees (pp. 39-49). Honey Bee Colony Health: Challenges and Sustainable Solutions. CRC, Boca Raton

Collins A.M., Donoghue A.M. (1999) Viability assessment of honey bee, Apis mellifera, sperm using dual fluorescent staining. Theriogenology 51 (8), 1513-1523

De Souza D.A., Bezzera-Laure M.A.F., Francoy T.M., Gonçalves L.S. (2013) Experimental evaluation of the reproductive quality of Africanized queen bees (Apis mellifera) on the basis of body weight at emergence. Genet. Mol. Res. 12 (4), 5382-5391

Delaney D.A., Keller J.J., Caren J.R., Tarpy D.R. (2011) The physical, insemination, and reproductive quality of honey bee queens (Apis mellifera L.). Apidologie 42 (1), 1-13
Esch H. (1988) The effects of temperature on flight muscle potentials in honeybees and cuculiinid winter moths. J. Exp. Biol. 135 , 109-117

Free J.B., Spencer-Booth Y. (1958) Observations on the temperature regulation and food consumption of honeybees (Apis mellifera ). J. Exp. Biol. 35 (4), 930-937

Free J.B., Spencer-Booth Y. (1960) Chill-coma and cold death temperatures of Apis mellifera. Entomol. Exp. Appl. 3 (3), 222-230

Goller F., Esch H. (1990) Comparative study of chill-coma temperatures and muscle potentials in insect flight muscles. J. Exp. Biol. 150 (1), 221-231

Guo X., Zhang L., Zhao J., Zhao E., Wei Y., Yan S. (2018) Thermoregulation capacity of honeybee abdomen for adaptability to the ambient temperature. Journal of Bionic Engineering 15(6), 992-998

Hoover S.E., Keeling C.I., Winston M.L., Slessor K.N. (2003) The effect of queen pheromones on worker honey bee ovary development. Naturwissenschaften $90(10), 477-480$

Human H., Nicolson S.W., Dietemann V. (2006) Do honeybees, Apis mellifera scutellata, regulate humidity in their nest? Naturwissenschaften 93 (8), 397-401

Kleinhenz M., Bujok B., Fuchs S., Tautz J. (2003) Hot bees in empty broodnest cells: heating from within. J. Exp. Biol. 206 (23), 4217-4231

Kraus F.B., Neumann P., Moritz R.F.A. (2005) Genetic variance of mating frequency in the honeybee (Apis mellifera L.). Insect. Soc. 52 (1), 1-5

Laidlaw H.H., Page R.E. (1984) Polyandry in honey bees (Apis mellifera L.): sperm utilization and intracolony genetic relationships. Genetics 108 (4), 985-997

Medrzycki P., Sgolastra F., Bortolotti L., Bogo G., Tosi S., Padovani E., Porrini C., Sabatini A.G. (2010) Influence of brood rearing temperature on honey bee development and susceptibility to poisoning by pesticides. J. Apic. Res. 49(1), 52-59

Moritz R.F. (1984) The effect of different diluents on insemination success in the honeybee using mixed semen. J. Apic. Res. 23 (3), 164-167

Nelson D.L. (1987). The effect of short-term storage methods on the weight of queen honeybees. J. Apic. Res. 26 (4), 240-242. https://doi.org/10.1080 /00218839.1987.11100767

Pankiw T., Huang Z.-Y., Winston M.L., Robinson G.E. (1998) Queen mandibular gland pheromone influences worker honey bee (Apis mellifera L.) foraging ontogeny and juvenile hormone titers. J. Insect Physiol. 44 (7-8), 685-692

Pettis J.S., Rice N., Joselow K., Chaimanee V. (2016) Colony failure linked to low sperm viability in honey bee (Apis mellifera) queens and an exploration of potential causative factors. PLoS One 11 (2), e0147220

R Development Core Team. (2008). R: A language and environment for statistical computing. R Foundation for Statistical Computing, Vienna, Austria.ISBN 3900051-07-0, (http://www.R-project.org). 
Reid M. (1975) Storage of queen honeybees. Bee World 56(1), 21-31

Rhodes, J.W. (2008) Semen production in drone honeybees [online]. Publication No 08/130. Rural Industries

Sammataro D., Finley J., Camazine S. (1999) Shipping conditions of honey bee queen. Am. Bee J., 713-716

Seitz N., Traynor K.S., Steinhauer N., Rennich K., Wilson M.E., Ellis J.D., Rose R., Tarpy D.R., Sagili R.S., Caron D.M., Delaplane K.S., Rangel J., Lee K., Baylis K., Wilkes J.T., Skinner J.A., Pettis J.S., vanEngelsdorp D. (2016) A national survey of managed honey bee 2014-2015 annual colony losses in the USA. J. Apic. Res. https://doi.org/10.1080 /00218839.2016.1153294

Southwick E.E., Heldmaier G. (1987) Temperature control in honey bee colonies. Bioscience 37 (6), 395-399

Stabentheiner A., Kovac H., Hetz S.K., Käfer H., Stabentheiner G. (2012) Assessing honeybee and wasp thermoregulation and energetics - new insights by combination of flow-through respirometry with infrared thermography. Thermochim. Acta 534, 77-86

Szabo T.I., Mills P.F., Heikel D.T. (1987) Effects of honeybee queen weight and air temperature on the initiation of oviposition. J. Apic. Res. 26 (2), 73-78. https://doi. org/10.1080/00218839.1987.11100740

Tarpy D.R., Hatch S., Fletcher D.J. (2000) The influence of queen age and quality during queen replacement in honeybee colonies. Anim. Behav. 59 (1), 97-101
Tarpy D.R., Keller J.J., Caren J.R., Delaney D.A. (2012) Assessing the mating "health" of commercial honey bee queens. J. Econ. Entomol. 105(1), 20-25

Tautz J., Maier S., Groh C., Rössler W., Brockmann A. (2003) Behavioral performance in adult honey bees is influenced by the temperature experienced during their pupal development. Proc. Natl. Acad. Sci. 100 (12), 7343-7347

van Engelsdorp D., Meisner M.D. (2010) A historical review of managed honey bee populations in Europe and the United States and the factors that may affect them. J. Invertebr. Pathol. 103, S80-S95

vanEngelsdorp D., Tarpy D.R., Lengerich E.J., Pettis J.S. (2013) Idiopathic brood disease syndrome and queen events as precursors of colony mortality in migratory beekeeping operations in the eastern United States. Prev. Vet. Med. 108(2-3), 225-233

Winston M.L. (1987) The Biology of the Honey Bee. Harvard University Press, Cambridge

Withrow J.M., Pettis J.S., Tarpy D.R. (2019) Effects of temperature during package transportation on queen establishment and survival in honey bees (Hymenoptera: Apidae). J. Econ. Entomol. 112 (3), 1043-1049

Publisher's note Springer Nature remains neutral with regard to jurisdictional claims in published maps and institutional affiliations. 